\title{
The Effects of Kefir Usage for Probiotic Purpose on Growth Performance of Brook Trout (Salvelinus fontinalis)
}

\author{
Huriye Ariman Karabulut ${ }^{1}$, Ilker Zeki Kurtoglu ${ }^{1} \&$ Ozay Kose ${ }^{1}$ \\ ${ }^{1}$ Department of Aquaculture, Faculty of Fisheries, Recep Tayyip Erdogan University, Rize, Turkey \\ Correspondence: Huriye Ariman Karabulut, Department of Aquaculture, Faculty of Fisheries, Recep Tayyip \\ Erdogan University, Rize, Turkey. Tel: 90-535- 619-2784. E-mail: huriye.ariman@erdogan.edu.tr
}

Received: July 5, 2018

Accepted: September 2, $2018 \quad$ Online Published: October 15, 2018

doi:10.5539/jas.v10n11p101

URL: https://doi.org/10.5539/jas.v10n11p101

\begin{abstract}
The effects of probiotically used kefir on growth, survival rate and meat yield characteristics of brook trout (Salvelinus fontinalis) were investigated in this study. For this purpose, kefir was added to trial diets at different rates $20 \mathrm{ml} / \mathrm{kg}$ feed (G2), $40 \mathrm{ml} / \mathrm{kg}$ feed (G3) while commercial fish feed was used as a control $0 \mathrm{ml} / \mathrm{kg}$ feed (G1). Total 270 fish with mean weight $24.38 \pm 0.37 \mathrm{~g}$ were used during the experiment. Each group had three replicate, and 30 fish were placed in each tank. Experiment was carried on for 90 days. At the end of the experiment, some growth parameters, survival rate and meat yields of the groups were determined.

The best weight gain (WG), specific growth rate (SGR), feed conversion ratio (FCR) and survival rate (SR) values were obtained in $\mathrm{G} 2(20 \mathrm{ml} / \mathrm{kg})$ group $(104.31 \pm 0.11,1.30 \pm 0.08,1.40 \pm 0.18,98.88 \pm 0.51$ respectively $)$. At the end of the study, the differences between the control group and the other groups were not statistically significant in terms of FCR, Condition factor $(\mathrm{CF})$ and survival rate $(\mathrm{P}<0.05)$. However, the differences between the control group and the other groups were statistically significant in terms of $W G, W G R$ and $\mathrm{W}_{\mathrm{f}}(\mathrm{P}<$ 0.05). The statistical difference between the G2 group and the G1 group was not significant at the SGR, whereas the statistical difference between the G2 group and the G3 group was significant $(\mathrm{P}<0.05)$.

The body composition of the fish, hepatosomatic index (HSI), viscerosomatic index (VSI) values, fish meat crude protein and crude fat content were not affected by the addition of kefir to fish diet at different ratios. As a result, it was observed that the addition of kefir at $20 \%$ of the diet positively affected the growth performance and survival rate of the brook trout.
\end{abstract}

Keywords: Salvelinus fontinalis, kefir, growth, survival rate

\section{Introduction}

As in aquaculture, the goal of all sectors of farming is yield. The idea behind using feed additives to increase yield is to affect the metabolism of the animal and increase its rate of utilizing the feed. This way, it is possible to achieve healthy development and higher yield with less feed (Karabulut, 2008). Several studies used probiotics to increase growth performance and strengthen immune systems of farmed fish (Korkut et al., 2003). Probiotics are microorganisms that are known to be beneficial to living beings which compete with pathogenic bacteria in cultivation conditions and are not pathogenic or toxic (Yaman, 2000; Ozdemir \& Kelestemur, 2009).

According to the Turkish Food Codex Communique on Fermented Milk Products, kefir is a milk product that is a dairy product that fermentes lactose in fermentation (Kluyveromces morxianus) and has yeast cells (Saccharomyces unisporus, Saccharomyces cerevisiae and Saccharomycess exiguus) that do not ferment lactose. However, in the fermentation process, Kefir grains are used which have different strains of Lactobacillus kefir, Leuconostoc, Lactococcus and Acetobacter genus in particular (Anonymous, 2009). Kefir, active kefir grains added to milk, is a dairy product formed as a result of lactic acid and ethyl alcohol fermentations (Guzel Seydim et al., 2000). Kefir, which is similar in contents to yogurt, contains various beneficial bacteria and yeasts, especially species of Lactobacillus (Rea et al., 1996; Jianzhong et al., 2009).

Kefir grains are yellowish white in color, irregularly shaped, similar to cauliflower, 3-20 mm in diameter. When kefir grains are added into the milk $\left(25^{\circ} \mathrm{C}\right.$ and 22 hours) they ferment the milk and reveal the kefir product. Kefir grains can be removed by filtration through the kefir product and used again in the next process. As the process repeats over time, kefir grains grow volumetrically and multiply (Guzel-Seydim et al., 2000). 
Kefir grains filtered through kefir product can be kept in water for 10 days at $4{ }^{\circ} \mathrm{C}$ after being washed with cold water (Yıldız, 2009). Bacteria and yeasts in kefir grains are found embedded in a matrix of polysaccharide structure called "Kefiran" (Frengova et al., 2002; Riamada \& Abraham, 2006). Kefiran, an exopolysaccharide of lactobacilli species, constitutes $24 \%$ of kefir dry matter (Micheli et al., 1999).

Microorganisms in kefir take position on the intestinal mucosa in the gastrointestinal track and facilitate increase and development of beneficial bacteria, while helping elimination of harmful yeasts and bacteria (Elena et al., 2007; Guzel-Seydim et al., 2011).

Various studies have been conducted on the effects of probiotics for growth performance and immunity parameters of different fish species (Bogut et al., 2000; Abd El-Rhman et al., 2009; Hedayat \& Bagheri, 2009; Mohapatra et al., 2012; Andani et al., 2012). However, there are a limited number of studies which focused on using kefir, which has probiotic properties, in aquaculture. The studies that were reviewed usually focused on the Coruh trout and the rainbow trout (Can et al., 2012a; Can et al., 2012b; Can et al., 2014; Ulukoy et al., 2015; Ulukoy et al., 2016; Gumus et al., 2017). In Turkey, commercial probiotic products are usually imported from abroad and this increases feed costs (Karademir et al., 2012). On the other hand, kefir is a feed additive, which is produced easily and with low costs.

In the Eastern Black Sea Region of Turkey, in addition to the dominant aquaculture species of the rainbow trout, producers also farm the brook trout (S. fontinalis) to attract consumers or as a hobby (Okumus et al., 1998). While several studies were conducted in Turkey on the rainbow trout (Karabulut et al., 2011), no study was found that have investigated usage of kefir in feed for the brook trout.

This study investigated the effects of adding kefir into feed of trout in different ratios on live weight gain, specific growth rate, condition factor, feed conversion ratio, survival rate and flesh yield characteristics in brook trout (S. fontinalis).

\section{Material and Methods}

\subsection{Experiment Area and Fish Material}

The study was carried out at experiment unit in the Recep Tayyip Erdogan University Fisheries and Aquaculture Application and Research Center. In the study randomly selected 270 brook trout (Salvelinus fontinalis) were used, whose weights varied between 20 and $30 \mathrm{~g}$ (mean: $24.38 \pm 0.37 \mathrm{~g}$ ). The fish were randomly distributed into $80 \mathrm{~L}$ fiberglass tanks by 3 groups with 3 replications such that there would be 30 fish per tank. The $4 \mathrm{~L} / \mathrm{min}$ average water flow was provided to the tanks. According to the measurements, the water temperature value was changed between $7{ }^{\circ} \mathrm{C}$ and $12{ }^{\circ} \mathrm{C}$, dissolved oxygen value was $5-6 \mathrm{mg} / \mathrm{L}$ and $\mathrm{pH}$ was approximately 7.5-7.8, while the study was conducted in a natural photoperiod during winter.

\subsection{Feed Material, Kefir Preparation and Bacteriological Analysis}

The study used a feed that consisted of fish meal, fish oil, grain products and vitamin A and mineral mixture which contained $47 \%$ crude protein, $20 \%$ crude fat, $2 \%$ crude cellulose, $10 \%$ humidity, $10 \%$ ash and 3330 $\mathrm{kcal} / \mathrm{kg}$ of metabolic energy.

Natural kefir grains were used in kefir production. Kefir grains were added 1 liter warm milk in the jar $(5 \% \mathrm{v} / \mathrm{w})$ and kept in dark for 20 hours at 22 degrees celsius (Guven et al., 2003).

Kefir grains were separated by sieving after the fermentation process and kept ready in the fridge in the water (4 ${ }^{\circ} \mathrm{C}$ ) for the next fermentation process. The resulting kefir product was also stored in refrigerated conditions until the experimental feed was prepared. The kefir product added feeds were prepared daily. Prepared kefir product was not used as feed additive if it was stored for more than 3 days (Guven et al., 2003). The experimental feeds were supplied with kefir product in previously determined rates (G1 (control): $40 \mathrm{ml}$ distilled water $/ \mathrm{kg}$ feed +0 $\mathrm{ml} \mathrm{kefir} / \mathrm{kg}$ feed; G2: $20 \mathrm{ml}$ distilled water $+20 \mathrm{ml} \mathrm{kefir} / \mathrm{kg}$ feed; $\mathrm{G} 3: 0 \mathrm{ml}$ distilled water $+40 \mathrm{ml} \mathrm{kefir} / \mathrm{kg}$ feed). After drying at $20^{\circ} \mathrm{C}$ in a fan-drying oven of the feeds, they were covered with fish oil ( $30 \mathrm{ml} \mathrm{fish} \mathrm{oil} / \mathrm{kg}$ feed). The feeds prepared every week were stored in plastic packages in a refrigerator $\left(4{ }^{\circ} \mathrm{C}\right)$. The feeds were given to the fish along the 90 days ( $3 \% \mathrm{~kg} /$ fish weight).

For the bacterial analysis of kefir, $25 \mathrm{ml}$ of kefir product was mixed with $225 \mathrm{ml}$ of peptone water (Oxoid Ltd., Hampshire, UK). This homogenate ten-fold dilution solutions were prepared in the same solution and $0.1 \mathrm{ml}$ of parallel plates were spread from these dilution tubes. Lactobacilli were analyzed using MRS (Oxoid CM361) agar and Lactic streptococci were counted using M17 agar (Oxoid CM785). The yeasts were analyzed using potato dextrose agar (Oxoid CM139) (Harrigan \& McCance 1976). In this study, Lactobacillus helvetis, 
Leuconostoc mesenteroides, Kluyveromyces mesenteroides and Pichia fermentes were detected as lactic acid bacteria and yeasts in kefir grains.

\subsection{Experiment Design}

The experiment was conducted in a $3 \times 3$ factorial order based on a completely chance-based experimental plan with one control $0 \mathrm{ml} / \mathrm{kg}$ feed (G1) and two experimental groups $20 \mathrm{ml} / \mathrm{kg}$ feed (G2); $40 \mathrm{ml} / \mathrm{kg}$ feed (G3). In total, 270 fish with the mean weight of $24.38 \pm 0.37 \mathrm{~g}$ were randomly distributed into 9 tanks such that each tank would contain 30 fish, and fed with the feeds for 90 days. The feeding was based on water temperature and fish weight in all diets and applied in three meals as morning, afternoon and evening (09:00, 13:00 and 17:00, respectively) by hand. The fish were fed in equal amounts in each meal by $3 \%$ of their body weight.

Growth of the fish was monitored every 15 days by a digital precision scale with $\pm 0.1 \mathrm{~g}$ precision and a von Bayer trough with $\pm 1 \mathrm{~mm}$ precision (Piper et al., 1983).

\subsection{Sample Collection and Analyses}

All fish in each tank were weighed and counted at the beginning and at the end of the experiment. Ten fish were sampled for analysis of initial whole body composition. At the end, 4 fish from each tank randomly collected (totally 36 fish) and were used to determine carcass yield, hepatosomatic index (HSI), viscerosomatic index (VSI) and fish meat nutrient content values. All samples were stored at a temperature of $-20{ }^{\circ} \mathrm{C}$ before analysis. The composition of the fish meat was analyzed in three parallels based on AOAC (2000) for crude protein, crude fat, crude ash and dry matter.

\subsection{Statistical Analysis}

At the end of the study, the experiments were carried out as three repetitions. Obtained findings are shown as the standard deviation of the mean. Sigma Plot 11.0 package programs were used so as to evaluate the findings of the present study. ONE WAY ANOVA test was used to determine differences between groups. When the difference statistically significant, the Holm-Sidak test was used to determine the difference between the groups. The differences between the groups were evaluated according to the degree of importance $\mathrm{P}<0.05$ (Duzgunes et al., 1993).

\section{Results}

Table 1 presents the findings of this study which investigated the effects of kefir added onto the feed of the brook trout (Salvelinus fontinalis) in different rates on growth performance, feed conversion ratio and survival rate. During the study period, data were collected and examined over 15 days periods. According to this, live weight gain, specific growth rates, Feed conversion ratio (FCR) values and temperature changes were determined for each period. 
Table 1. Growth parameters obtained from experimental groups at the end of the study

\begin{tabular}{llll}
\hline \multirow{2}{*}{ Parameters } & \multicolumn{3}{c}{ Experiment Groups } \\
\cline { 2 - 4 } & G1 $(0 \mathrm{ml} / \mathrm{kg})$ & $\mathrm{G} 2(20 \mathrm{ml} / \mathrm{kg})$ & $\mathrm{G} 3(40 \mathrm{ml} / \mathrm{kg})$ \\
\hline $\mathrm{N}_{\mathrm{i}}$ & 90 & 90 & 90 \\
$\mathrm{~N}_{\mathrm{f}}$ & $89.33 \pm 0.57^{\mathrm{a}}$ & $87.00 \pm 1.00^{\mathrm{bc}}$ & $86.66 \pm 1.15^{\mathrm{bc}}$ \\
$\mathrm{W}_{\mathrm{i}}(\mathrm{g})$ & $24.37 \pm 0.23^{\mathrm{a}}$ & $24.36 \pm 0.47^{\mathrm{b}}$ & $24.41 \pm 0.43^{\mathrm{a}}$ \\
$\mathrm{W}_{\mathrm{f}}(\mathrm{g})$ & $121.51 \pm 0.45^{\mathrm{a}}$ & $128.67 \pm 0.43^{\mathrm{b}}$ & $116.38 \pm 0.16^{\mathrm{c}}$ \\
$\mathrm{L}_{\mathrm{i}}(\mathrm{cm})$ & $13.38 \pm 0.06^{\mathrm{a}}$ & $13.34 \pm 0.07^{\mathrm{a}}$ & $13.35 \pm 0.04^{\mathrm{a}}$ \\
$\mathrm{L}_{\mathrm{f}}(\mathrm{cm})$ & $23.90 \pm 0.13^{\mathrm{a}}$ & $25.00 \pm 0.16^{\mathrm{b}}$ & $20.20 \pm 0.09^{\mathrm{a}}$ \\
$\mathrm{WG}^{\mathrm{a}}(\mathrm{g})$ & $97.14 \pm 0.17^{\mathrm{a}}$ & $104.31 \pm 0.11^{\mathrm{b}}$ & $91.97 \pm 0.10^{\mathrm{c}}$ \\
${ }^{1} \mathrm{WGR}(\%)$ & $398.60 \pm 0.21^{\mathrm{a}}$ & $428.20 \pm 0.24^{\mathrm{b}}$ & $376.77 \pm 0.14^{\mathrm{c}}$ \\
${ }^{2} \mathrm{SGR}(\%)$ & $1.25 \pm 0.02^{\mathrm{ab}}$ & $1.30 \pm 0.08^{\mathrm{b}}$ & $1.20 \pm 0.05^{\mathrm{ac}}$ \\
${ }^{3} \mathrm{FCR}$ & $1.47 \pm 0.16^{\mathrm{a}}$ & $1.40 \pm 0.18^{\mathrm{a}}$ & $1.55 \pm 0.25^{\mathrm{a}}$ \\
${ }^{4} \mathrm{CF}$ ( $\left.\%\right)$ & $1.00 \pm 0.05^{\mathrm{a}}$ & $1.02 \pm 0.03^{\mathrm{a}}$ & $1.02 \pm 0.03^{\mathrm{a}}$ \\
${ }^{4} \mathrm{CF} F_{\mathrm{f}}(\%)$ & $1.46 \pm 0.07^{\mathrm{a}}$ & $1.59 \pm 0.11^{\mathrm{a}}$ & $1.43 \pm 0.07 \mathrm{a}$ \\
${ }^{5} \mathrm{SR}(\%)$ & $95.55 \pm 1.37^{\mathrm{a}}$ & $98.88 \pm 0.51^{\mathrm{a}}$ & $97.77 \pm 1.16^{\mathrm{a}}$ \\
\hline
\end{tabular}

Note. Values are mean \pm standard deviation. Values in the same row with different superscripts are significantly different $(\mathrm{P}<0.05)$.

i: Initial, f: Final.

${ }^{1}$ Weight gain rate WGR $(\%)=100 \times(\mathrm{Wf}-\mathrm{Wi}) / \mathrm{Wi}($ Shiau \& Chen, 1992);

${ }^{2}$ Specific growth rate, SGR $\left(\%\right.$ day $\left.^{-1}\right)=[($ Ln Wf - Ln Wi $) /$ days $] \times 100$ (Hopkins, 1992);

${ }^{3}$ Feed conversion ratio, FCR $=$ dry feed intake $(\mathrm{g}) /$ weight gain $(\mathrm{g})$ (Imsland et al., 2001);

${ }^{4}$ Condition factor, $\mathrm{CF}(\%)=\left(\mathrm{W} / \mathrm{L}^{3}\right) \times 100($ Avsar, 2005);

${ }^{5}$ Survival rate, $(\mathrm{SR})(\%)=\left[\right.$ final fish number $\left(\mathrm{N}_{\mathrm{f}}\right) /$ initial fish number $\left.\left(\mathrm{N}_{\mathrm{i}}\right)\right] \times 100($ Celikkale, 2002$)$.

At the end of the experiment, final growth weight (Wf), weight gain (WG), specific growth rate (SGR) and FCR values of G2 group, fed with $20 \mathrm{ml} / \mathrm{kg}$ kefir supplemented diet, were $128.67 \pm 0.43 ; 104.31 \pm 0.11 ; 1.30 \pm 0.08$; $1.40 \pm 0.18$, respectively. It was determined that statistical differences between the groups were significant in terms of final growth weight $(\mathrm{Wf})$ and weight gain $(\mathrm{WG})(\mathrm{P}<0.05)$. The statistical difference between the G2 group and the G1 group was not significant at the specific growth rate (SGR), whereas the statistical difference between the G2 group and the G3 group was significant $(P<0.05)$. The difference in FCR expression between all groups was insignificant $(\mathrm{P}<0.05)$.

The number of fish that died during the trial period was recorded daily and compared with the survival rate at the end of the study. The highest survival rate was determined in G2 $(98.88 \pm 0.51)$ and the lowest in G1 $(95.55 \pm 1.37)$. The difference between all groups was statistically insignificant $(\mathrm{P}<0.05)$. At the end of the study, the condition factor (CF) was determined in groups G1, G2 and G3 $(1.46 \pm 0.07 ; 1.59 \pm 0.11 ; 1.43 \pm 0.07$, respectively). The difference between the groups was found to be insignificant $(\mathrm{P}<0.05)$.

It was determined that the difference in statistics between the groups in the increase in live weight started to emerge after the 30th day. According to this, the difference between G3 and G1 group was found to be insignificant while the difference between G3 and G2 group was found to be significant and the difference between G1 and G2 group was found to be insignificant $(\mathrm{P}<0.05)$. After 45th, 60th, 75th, 90th days, the difference between all groups was significant $(\mathrm{P}<0.05)$. The best live weight gain for each period was determined to be the G2 Group fed with $20 \mathrm{ml} / \mathrm{kg}$ kefir supplemented feed (Figure 1). 


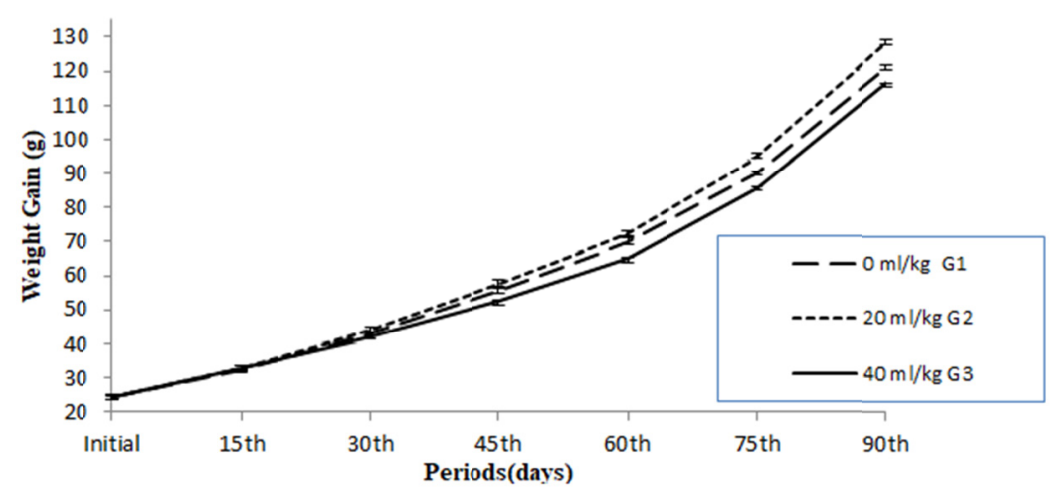

Figure 1. The individual mean live weights of the fish in the experimental groups according to baseline and periods (mean \pm std)

Specific growth rate (SGR) was highest in G2 group at 15th day (2.001 \pm 0.08$)$ of study and G3 group at 90th day $(2.029 \pm 0.05)$. On the other hand, G3 group was found to be the lowest value at 45th day $(1.435 \pm 0.05)$ and 60th day $(1.430 \pm 0.08)$. The 60 th day was defined as the period in which specific growth for all groups was measured as the lowest values. On the 30th day and 45th day, the G3 group was statistically different from the G1 and G2 groups $(\mathrm{p}<0.05)$ (Figure 2).

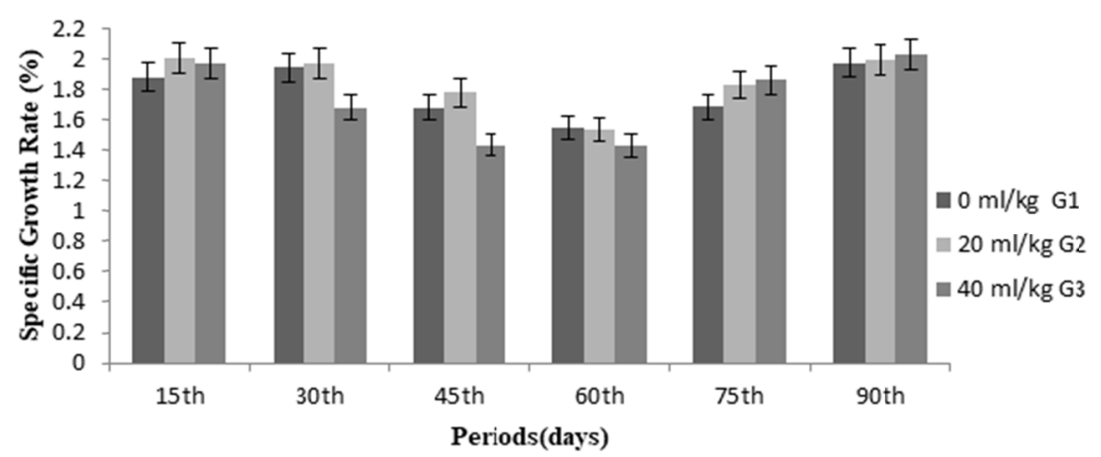

Figure 2. The individual mean Specific Growth Rate (\%) of the fish in the experimental groups according to baseline and periods (mean \pm std)

When the FCR values were compared according to the periods, it was found to be parallel to the specific growth rates. The highest FCR values were found in the G3 group, at the 45th (1.851 \pm 0.25$)$ and 60th day $(1.837 \pm 0.21)$, while the lowest FCR value was found in the G2 group at the 90th day (1.226 \pm 0.19$)$. At the 30th and 60th days, G3 group was found statistically significant with $\mathrm{G} 1$ and G2 groups $(\mathrm{P}<0.05)$ (Figure 3).

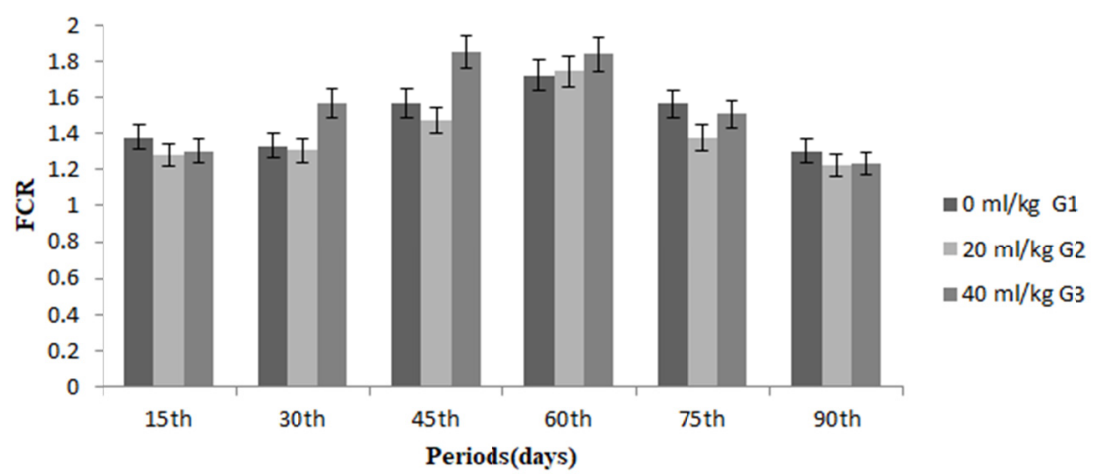

Figure 3. The individual FCR of the fish in the experimental groups according to baseline and periods (mean \pm std) 
During the study period, water temperatures were recorded daily and averaged over a period of 15 days. The mean water temperature values were $8.071 \pm 0.82{ }^{\circ} \mathrm{C}$ lowest at 60 th day of study and $10.928 \pm 0.73{ }^{\circ} \mathrm{C}$ highest at 90th day of study. It has been determined that water temperature values are in parallel with FCR and SGR values (Figure 4).

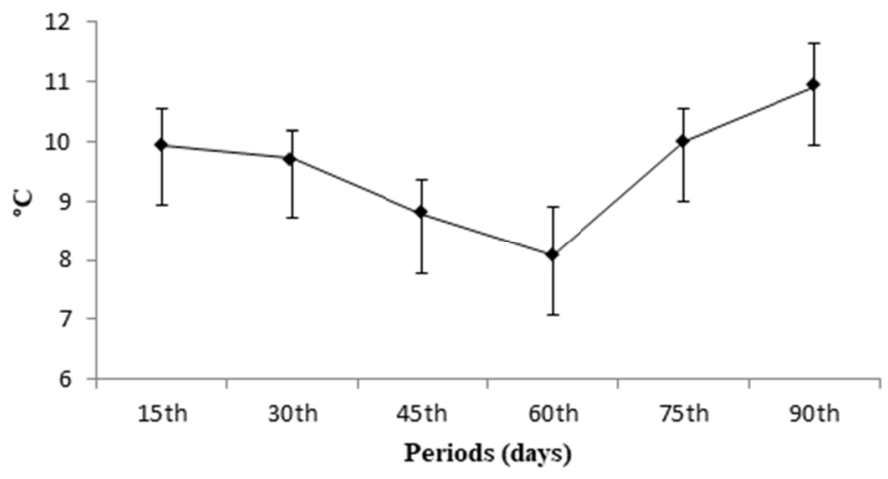

Figure 4. Changes in the mean temperature of water throughout the study period (mean \pm std)

The four fish from each tank randomly collected (totally 36 fishes) and were used to determine carcass yield (CY), hepatosomatic index (HSI), viscerosomatic index (VSI). The post-experiment CY, HSI and VSI values are given in Table 2. Addition of kefir to brook trout diet at different ratios did not reveal any abnormality in the liver of the autopsy examination. There was no statistically significant difference between $\mathrm{CY}$ and HSI values ( $\mathrm{P}$ $<0.05)$. For VSI values, the difference between groups G1 and G3 was significant $(\mathrm{P}<0.05)$.

Table 2. Carcass Yield (CY), Hepatosomatic Index (HSI) and Viscerosomatic Index (VSI) values obtained from the groups

\begin{tabular}{lllll}
\hline \multirow{2}{*}{ Parameters } & \multirow{2}{*}{ Initial (N=10) } & \multicolumn{3}{c}{ Experiment Groups } \\
\cline { 2 - 5 } & & $0 \mathrm{ml} / \mathrm{kg} \mathrm{G1}(\mathrm{N}=12)$ & $20 \mathrm{ml} / \mathrm{kg} \mathrm{G} 2(\mathrm{~N}=12)$ & $40 \mathrm{ml} / \mathrm{kg} \mathrm{G} 3(\mathrm{~N}=12)$ \\
\hline CY (\%) & $80.02 \pm 11.51$ & $80.06 \pm 13.23^{\mathrm{a}}$ & $82.60 \pm 10.21^{\mathrm{a}}$ & $74.59 \pm 10.50^{\mathrm{a}}$ \\
${ }^{1} \mathrm{HSI}(\%)$ & $2.25 \pm 0.36$ & $2.83 \pm 0.42^{\mathrm{a}}$ & $2.55 \pm 0.55^{\mathrm{a}}$ & $2.37 \pm 0.60^{\mathrm{a}}$ \\
${ }^{2}$ VSİ (\%) & $10,14 \pm 2.71$ & $16.43 \pm 2.64^{\mathrm{a}}$ & $15.20 \pm 2.63^{\mathrm{ab}}$ & $13.8 \pm 2.19^{\mathrm{b}}$ \\
\hline
\end{tabular}

Note. Values are mean \pm standard deviation. Values in the same row with different superscripts are significantly different $(\mathrm{P}<0.05)$.

${ }^{1}$ Hepatosomatic Index (HSI, \%) $=100 \times$ liver weight/body weight (Segato et al., 2006).

${ }^{2}$ Viscerosomatic Index (VSI, \%) $=100 \times$ viscera weight/body weight (Segato et al., 2006).

In the nutrient analyses of the fish meat after the experiment (Table 3), while there was no statistically significant difference between G2 and G3 in terms of crude protein and crude fat ratios, the difference between G1 and the other groups was found to be significant $(\mathrm{P}<0.05)$.

Table 3. Nutritional composition of the fish meat

\begin{tabular}{lllll}
\hline \multirow{2}{*}{ Parameters } & \multirow{2}{*}{ Initial $(\mathrm{N}=10)$} & \multicolumn{3}{c}{ Experiment Groups $(\mathrm{N}=5)$} \\
\cline { 3 - 4 } & & $0 \mathrm{ml} / \mathrm{kg} \mathrm{G} 1$ & $20 \mathrm{ml} / \mathrm{kg} \mathrm{G} 2$ & $40 \mathrm{ml} / \mathrm{kg} \mathrm{G} 3$ \\
\hline Dry matter (\%) & $21.07 \pm 0.37$ & $20.93 \pm 0.21^{\mathrm{a}}$ & $23.81 \pm 0.14^{\mathrm{b}}$ & $24.67 \pm 0.23^{\mathrm{cb}}$ \\
Crude protein (\%) & $19.12 \pm 0.46$ & $19.18 \pm 0.15^{\mathrm{a}}$ & $19.30 \pm 0.12^{\mathrm{b}}$ & $19.34 \pm 0.08^{\mathrm{b}}$ \\
Crude lipid (\%) & $2.18 \pm 0.50$ & $2.41 \pm 0.06^{\mathrm{a}}$ & $2.70 \pm 0.20^{\mathrm{b}}$ & $2.76 \pm 0.06^{\mathrm{b}}$ \\
Crude ash (\%) & $1.09 \pm 0.43$ & $1.02 \pm 0.12^{\mathrm{a}}$ & $1.17 \pm 0.16^{\mathrm{a}}$ & $0.98 \pm 0.13^{\mathrm{a}}$ \\
\hline
\end{tabular}

Note. Values are mean \pm standard deviation. Values in the same row with different superscripts are significantly different $(\mathrm{P}<0.05)$. 


\section{Discussion}

This study added kefir into a commercial trout feed in different rates $(0 \mathrm{ml} / \mathrm{kg}$ feed $\mathrm{G} 1,20 \mathrm{ml} / \mathrm{kg}$ feed $\mathrm{G} 2,40$ $\mathrm{ml} / \mathrm{kg}$ feed G3). It was aimed to determine the advantages of using kefir in trout feeds by determining the effects of kefir addition on growth, survival rate and meat chemical composition in the brook trout. As a result of the 90-day experiment period, the best weight gain and specific growth rate values in this study were found in the second group G2, which had a $20 \mathrm{ml} / \mathrm{kg}$ feed of kefir addition. Similarly, Can et al. (2012a) added different doses of kefir (0,10, 20 and $40 \mathrm{~g} / \mathrm{kg}$ ) into feed of the Coruh trout (Salmo coruhensis) for different periods (2 months and 3 months), and found that the highest increase in weight among the groups was in the group with $20 \mathrm{~g} / \mathrm{kg}$ kefir addition by $43.51 \pm 1.08 \mathrm{~g}$ after 3 months. Another study added kefir into diets prepared for tilapia fish in different rates and with sodium alginate as a binding agent to feed the fish for 50 days, and observed that the growth performance of the fish increased (Van Doan et al., 2017). Another study on tilapia fish determined that supplementing probiotic additives into feed increased growth performance (El-Haroun et al., 2006). Van Doan et al. (2016) fed pangasius fish with 4 different feeds containing yeast and probiotics, and found that specific growth rates on the $30^{\text {th }}, 60^{\text {th }}$ and $90^{\text {th }}$ were higher in the yeast and probiotics groups in comparison to the control group.

The rate of biochemical reactions of ectothermic animals is affected by water temperature (Angilletta et al., 2002). As a result, growth, growth rates and physiological properties associated with those are affected (Jonsson \& L'Abee-Lund, 1993). In this study, it was determined that SGR values obtained during the study periods in all groups showed a decrease until the 60th day from the beginning of the study and started to rise again after 60th day. Correspondingly, the FCR values increased from the beginning of the study to the 60th day and began to fall again after the 60th day. This condition is thought to be caused by changes in water temperature throughout the study period. As shown in Figure 4, the average water temperature at the beginning of the study decreased until the 60th day of the study. It has been determined that this situation decreases in the SGR values and that the FCR values are in parallel with the beginning of the negative trend. While the SGR values are beginning to increase as the water temperature starts to rise again after the 60th day, the FCR values support this suggestion as the water temperature starts to improve with increasing water temperature.

While this study reached the conclusion that kefir addition improved feed utilization, the results were in parallel to those of a study which reported that kefir addition did not affect feed conversion ratio (Gumus et al., 2017). There are also other studies which reported that probiotics addition improved feed utilization (El-Haroun et al., 2006; Van Doan et al., 2016). Different literature reports on feed utilization rates may have resulted out of differences in the microorganism content of the probiotic used, its quantity, application duration, the species of fish and the age of fish.

In aquaculture, one of the successes obtained by using kefir for probiotic purposes is that it increases survival rates and reduces stress signs. The best survival rate in this study was found in the group G2 with $20 \mathrm{ml} / \mathrm{kg}$ feed kefir addition by $98.88 \pm 0.51 \%$. Another study added kefir into feed of the rainbow trout in different rates $(2.5$ and $10 \%$ ), and found that $10 \%$ kefir-supported feed provided a significant increase in the immunity values of the fish and increased its survival rate against disease factors (Gumus et al., 2017). In a study by El-Haroun et al., (2006) on tilapia fish, it was reported that adding probiotics into feed in different rates reduced the effect of stressors. In another study on tilapia fish, diets were supported by a binding agent and kefir in different rates, the fish were fed for 50 days, and it was found that kefir reduced mortality by affecting the immune system positively (Van Doan et al., 2017).

In the study, brook trout fed diets supplemented with kefir at different rates were found to decrease in HSI and VSI index values as the kefir ratio increased. The cause of this differentiation may be due to the fact that the rate of lubrication in fish is different depending on the kefir ratio. Similarly, in a study conducted by Chen et al. (2014), leptin deficient mice fed at a dose of $140 \mathrm{mg} / \mathrm{kg} \mathrm{g}^{-1}$ for 4 weeks and as a result, they reported that kefir inhibited the lipogenesis pathway and treated liver fat syndrome.

\section{Conclusions}

In consequence, it was determined that kefir addition into brook trout feed by $20 \mathrm{ml} / \mathrm{kg}$ had a positive effect on growth performance and survival rate, while kefir addition in a higher rate $(40 \mathrm{ml} / \mathrm{kg}$ feed) influenced the fish development negatively to an extent that was reflected in the growth performance of the fish by weight and length, its specific growth rate, and its survival rate. 


\section{References}

Abd El-Rhman, M. A., Khatab, Y. A., \& Shalaby, A. M. (2009). Micrococcus luteus and Pseudomonas species as probiotics for promoting the growth performance and health of Nile tilapia Oreochromis nilotcus. Fish and Shellfish Immunology, 27, 175-180. https://doi.org/10.1016/j.fsi.2009.03.020

Andani, H. R. R., Tukmechi, A., Meshkini, S., \& Sheikhzadeh, N. (2012). Antagonistcactvity of two potental probiotic bacteria from fish intestines and investigation of their effects on growth performance and immune response in rainbow trout (Oncorhynchus mykiss). Journal of Applied Ichthyology, 28, 728-734. https://doi.org/10.1111/j.1439-0426.2012.01974.x

Angilletta, M. J., Niewiarowski, P. H., \& Navas, C. A. (2002). The evolution of thermal physiology in ectotherms. Journal of Thermal Biology, 27, 249-268. https://doi.org/10.1016/S0306-4565(01)00094-8

Anonymous. (2009). Türk Gida Kodeksi Fermente Süt Ürünleri Tebliği. Sayl: 27143, Tebliğ No:2009/25.

AOAC. (2000). Official Methods of Analysis (17th ed., p. 238). Association of Official Analytical Chemist, Washington.

Avsar, D. (2005). Balıkcllık Biyolojisi ve Populasyon Dinamiği. Nobel Kitabevi, Adana.

Bogut, I., Milakovic, Z., Brkic, S., Novoselic, D., \& Bukvic, Z. (2000). Effects of Enterococcus faecium on the growth rate and intestinal microflora in sheat fish (Silurus glanis). Veterinarni Medicina, 45(4), 107-109.

Can, E., Kurtoglu, I. Z., Benzer, F., Erisir, M., Kocabaş, M., Kizak, V., Kayim, M., \& Celik, H. T. (2012a). The effects of different dosage of kefir with different durations on growth performances and antioxidant system in the blood and liver tissues of Coruh trout (Salmo coruhensis). Turkish Journal of Fisheries and Aquatic Sciences, 12, 277-283. https://doi.org/10.4194/1303-2712-v12_2_12

Can, E., Kutluyer, F., Sonay, F. D., \& Kose, O. (2012b). The use of kefir as potential probiotic in Çoruh trout (Salmo coruhensis): Effects on growth performance and immunoglobulin (IgM) levels. African Journal of Biotechnology, 11(30), 7775-7780. https://doi.org/10.5897/AJB11.3448

Can, S. S., Kutluyer, F., Can, E., Kayis, S., Sonay, F. D., Kose, O., Aksu, O., Erdamar, H., Yigitoglu, M. R., \& Kayim, M. (2014). Effect of dietary kefir on the digestive and liver enzymes activities and glucose level of Coruh trout, Salmo coruhensis (Actinopterygii: Salmoniformes: Salmonidae). Acta Ichthyologicaet Piscatoria, 44(2), 167. https://doi.org/10.3750/AIP2014.44.2.13

Celikkale, M. S. (2002). İ̧̧su Balıkları ve Yetiştiriciliği (Cilt 1, III Baskı). K.T.Ü., Sürmene Deniz Bilimleri Fakültesi Yayınları, Trabzon.

Duzgunes, O., Kesici, T., \& Gurbuz, F. (1993). İstatistik Metodlarl (II Baskı). Ankara Ünversitesi Ziraat Fakültesi Yayınları, Ankara.

Elena, U., Jaione, B., Patricia, A., Aurora, I., Florencio, M., \& Francisco, C. I. (2007). Intestinal beneficial effects of kefir supplemented diet in rats. Nutrition Research, 27, 653-658. https://doi.org/10.1016/ j.nutres.2007.08.002

El-Haroun, E. R., Goda, A. M. A., \& Kabir Chowdhury, A. M. (2006). Effect of dietary probiotic biogens supplementation as a growth promoter on growth performance and feed utilization of Nile Tilapia Oreochromis niloticus (L.). Aquaculture Research, 37, 1473-1480. https://doi.org/10.1111/j.1365-2109.2006. 01584.x

Frengova, G. I., Simova, E. D., Beshkova, D. M., \& Simov, Z. I. (2002). Exopolysaccharides produced by lactic acid bacteria of kefir grains. Zeitschrift für Naturforschung C, 57(9-10), 805-810. https://doi.org/10.1515/ znc-2002-9-1009

Gumus, E., Kubilay, A., Guney, S., Guzel-Seydim, Z., Kok-Tas, T., Metin, S., \& Ulukoy, G. (2017). Effect of dietary kefir on the growth performance, feed utilization and fatty acid profile of juvenile rainbow trout, Oncorhynchus mykiss. Aquaculture Nutrition, 23, 964-972. https://doi.org/ 10.1111/anu.12464

Guven, A., Guven, A., \& Gulmez, M. (2003). The Effect of Kefir on the Activities of GSH-Px, GST, CAT, GSH and LPO Levels in Carbon Tetrachloride-Induced Mice issues. Journal of Veterinary Medicine, 50, 412-416. https://doi.org/10.1046/j.1439-0450.2003.00693.x

Guzel-Seydim, Z, B., Kok-Tas, T., Greene, A. K., \& Seydim, A.C, (2011). Review: Functional properties of kefir. Critical Reviews in Food Science and Nutrition, 51(3), 261-268. https://doi.org/10.1080/1040839090 3579029 
Guzel-Seydim, Z. B., Seydim, A. C., Greene, A. K., \& Bodine, A. B. (2000). Determination of organic acids and volatile flavor substances in kefir during fermentation. Journal of Food Composition and Analysis, 13, 35-43. https://doi.org/10.1006/jfca.1999.0842

Harrigan, F. W., \& McCance, M. E. (1976). Laboratory Methods in Food and Dairy Microbiology. Academic Press, London.

Hedayat, A., \& Bagheri, T. (2009). The effect of probiotic (Bacillus spp.) on growth, survival, and innate immunity of rainbow trout (Onchorhynchus mykiss) fry during the first two months of feeding. Journal of Comparative Pathology, 141, 1. https://doi.org/10.1016/j.jcpa.2009.08.048

Hopkins, K. D. (1992). Reporting fish growth: A review of the basics. Journal of the World Aquaculture Society, 23(3), 173-179. https://doi.org/10.1111/j.1749-7345.1992.tb00766.x

Imsland, A. K., Foss, A., Gunnarsson, S., Berntssen, M., Fitz Gerald, R., Bonga, S. W., ... Stefansson, S. O. (2001). The interaction of temperature and salinity on growth and food conversion in juvenile turbot (Scophthalmus maximus). Aquaculture, 198, 353- 367. https://doi.org/ S0044-8486 $0100507-5$

Jianzhong, Z., Xiaoli, L., Hanhu, J., \& Mingsheng, D. (2009). Analysis of the microflora in Tibetan kefir grains using denaturing gradient gel electrophoresis. Food Microbiology, 26, 770-775. https://doi.org/10.1016/j.fm. 2009.04.009

Jonsson, B., \& L'Abee-Lund, J. H. (1993). Latitudinal clines in life history variables of anadromous brown trout in Europe. Journal of Fish Biology, 43(Suppl. A), 1-16. https://doi.org/10.1111/j.1095-8649.1993.tb01175.x

Karabulut, H. A. (2008). Balık yetiştiriciligi acısından anabolik ajanlar ve ilacların etkileri ve kalıntılarının degerlendirilmesi. Ege Universitesi Su Urunleri Dergisi, 25(1), 83-87.

Karabulut, H. A., Balta, F., Yandi, I., \& Serezli, R. (2011). The effects of different levels of ascorbic acid on growth performance and meat composition of brook trout (Salvelinus fontinalis). Kafkas Universitesi Veteteriner Fakultesi Dergisi, 17(2), 303-308.

Karademir, G., Yoruk, M. A., Tunc, M. A., \& Celebi, D. (2012). Yumurtacı Tavuklarda Kefirin Performans ve Yumurta Kalitesine Etkisi. Ataturk Universitesi Vet. Bil. Derg, 7(3), 177-184.

Korkut, A.Y., Hossu, B., \& Ferhatoglu, M. (2003). Probiyotikler ve su urunlerinde kullanımı. Ege Universitesi Su Urunleri Dergisi, 20(3-4), 551-556.

Micheli, L., Uccelletti, D., Palleschi, C., \& Crescenzi, V. (1999). Isolation ve characterization of a ropy Lactobacillus strain producing exopolysaccharide kefiran. Applied Microbiology ve Biotechnology, 53, 69-74. https://doi.org/10.1007/s002530051616

Mohapatra, S., Chakraborty, T., Prusty, A. K., Das, P., Paniprasad, K., \& Mohanta, K. N. (2012). Use of different microbial probiotics in the diet of rohu, Labeo rohita fingerlings: Effects on growth, nutrient digestibility and retenton, digestve enzyme actvites and intestinal microflora. Aquaculture Nutrition, 18, 1-11. https://doi.org/10.1111/j.1365-2095.2011.00866.x

Okumus, I., Bascinar, N., Alkan, M. Z., \& Kurtoglu, I. Z. (1998). Doğu Karadeniz sartlarında kaynak alabalı̆̆ının deniz ve tatlı sularda buyume ve kulture alma potansiyeli. Doğu Anadolu Bölgesi III Su Urunleri Sempozyumu, 10-12 Haziran 1998, Erzurum.

Ozdemir, Y., \& Kelestemur, G. T. (2009). Balık beslemede yem katkı maddesi olarak probiyotik kullanımının avantajlar1. Journal of New World Sciences Academy Ecological Life Sciences, 4(1), 6-11.

Piper, R. G., McElwain, L. B., Orme, L. F., McCraden, J. P., Fowler, L. G., \& Leonard, J. R. (1983). Fish Hatchery Management (p. 517), U.S. Fish and Wildlife Service, Washington D.C.

Rea, M.C., Lennartsson, T., Dillon, P., Drinan, F. D., Reville, W. J., Heapes, M., \& Cogan, T. M. (1996). Irish kefir-like grains: Their structure, microbial composition and fermentation kinetics. Journal Applied Bacteriology, 81, 83-94. https://doi.org/10.1111/j.1365-2672.1996.tb03286.x

Rimada, P. S., \& Abraham, A. G. (2006). Kefiran improves rheological properties of glucono- $\delta$-lactone induced skim milk gels. International Dairy Journal, 16(1), 33-39. https://doi.org/10.1016/j.idairyj.2005.02.002

Rodrigues, K. L., Lucelia, R. G. C., Jose, C. T. C., Joao, E., \& Jose, M. S. (2005). Antimicrobial and healing activity of kefir and kefiran extract. International Journal of Antimicrobial Agents, 25, 404-408. https://doi.org/10.1016/j.ijantimicag.2004.09.020 
Segato, S., Bertotto, D., Fasolato, L., Francescon, A., Barbaro, A., \& Corato, A. (2006). Effect of triploid on feed efficiency, morphometric indexes and chemical composition of shi drum (Umbrina cirrosa L.). Aquaculture Research, 37, 71-77. https://doi.org/ 10.1111/j.1365-2109.2005.01398.x

Shiau, S. Y., \& Chen, S. Y. (1992). The influence of dietary energy levels with and without PCB induction on the growth of tilapia, Oreochromis niloticus $\times$ Oreochromis aureus. Fish Physiology and Biochemistry, 10(4), 321-326. https://doi.org/10.1007/BF00004481

Ulukoy, G., Kubilay, A., Guzel-Seydim, Z., Gumus, E. S., Guney, S., Kok-Tas, T., ... Diler, O. (2015). Effect of storage temperature on benefcial microbial load in rainbow trout feed supplemented with kefir. The Indian Journal of Fisheries, 62,137-139.

Ulukoy, G., Metin, S., Kubilay, A., Guney, Ş., Yıldırım, P., Guzel-Seydim, Z., ... Gümüş, E. (2016). The effect of kefir as a dietary supplement on nonspecific immune response and disease resistance in juvenile rainbow trout, Oncorhynchus mykiss (Walbaum 1792). Journal of the World Aquaculture Society, 48, $248-256$. https://doi.org/10.1111/jwas. 12336

Van Doan, H., Doolgindachbaporn, S., \& Suksri, A. (2016). Effects of Eryngii mushroom (Pleurotus eryngii) and Lactobacillus plantarum on growth performance, immunity and disease resistance of pangasius catfish (Pangasius bocourti, Sauvage 1880). Fish Physiology and Biochemistry, 42, 1427-1440. https://doi.org/ 10.1007/s10695 -016-0230-6

Van Doan, H., Hoseinifar, S. H., Tapingkae, W., \& Khamtavee, P. (2017). The effects of dietary kefir and low molecular weight sodium alginate on serum immune parameters, resistance against Streptococcus agalactiae and growth performance in Nile tilapia (Oreochromis niloticus). Fish and Shellfish Immunology, 62, 139-146. https://doi.org/10.1016/j.fsi.2017.01.014

Yaman, H. (2000). Partial characterization of lactobacilli isolated from commercial kefir grain (PhD Thesis, Huddersfield University, Huddersfield, UK).

Yıldız, F. (2009). Farklı yă̆ oranlarının ve farklı starter kültürlerin kefirin nitelikleri üzerine etkisi (Doktora Tezi, Ankara Üniversitesi, Fen Bilimleri Enstitüsü, Ankara).

\section{Copyrights}

Copyright for this article is retained by the author(s), with first publication rights granted to the journal.

This is an open-access article distributed under the terms and conditions of the Creative Commons Attribution license (http://creativecommons.org/licenses/by/4.0/). 